Original Research

\title{
Assessment of the Socio-Economic Impact of a Water Diversion Project for a Water-Receiving Area
}

\author{
Zhuoyue Peng'*, Junxian Yin², Lili Zhang², Jing Zhao ${ }^{3}$, Yun Liang², \\ Hao Wang ${ }^{2}$ \\ ${ }^{1}$ Key Laboratory of Hydraulic Power Engineering of Jiangsu Province, College of Hydraulic Science and Engineering, \\ Yangzhou University, Yangzhou, China \\ ${ }^{2}$ China Institute of Water Resources and Hydropower Research, Beijing, China \\ ${ }^{3}$ College of Water Conservancy, North China University of Water Resources and Electric Power, Zhengzhou, China
}

Received: 1 November 2018

Accepted: 28 April 2019

\begin{abstract}
Finding a method to accurately evaluate a water diversion project's socio-economic impact, which can contribute to planning and decision-making, has become a hot issue in the world. Our paper constructs a computable general equilibrium model of a water diversion project for a water-receiving area to solve this issue, and takes the south-to-north water diversion project in Beijing, China as an example. With comparative analysis of different water supplies, the socio-economic impact of a water diversion project on the water-received area is evaluated quantitatively. The result shows that as the reduction of the water supply from the south-to-north water division project under different policy scenarios, the regional gross domestic product decreases, which means the economic level declines, the proportion of high water consumption by industry declines, the price index rises (which is not conducive to social stability), employment rate falls and unemployment rises, and per capita disposable income falls (reflecting that the quality of people's living standards is falling). This study provides a theoretical basis to allocate the diverted water and local water reasonably in order to adjust the industry structure according to the local situation, to improve water management, and to reform water market and water price.
\end{abstract}

Keywords: computable general equilibrium model, policy evaluation, socio-economy impact, water diversion project, water market of China

\section{Introduction}

Water is the foundation and lifeblood of social economic development and a healthy ecological system,

*e-mail: pengzhuoyue123@sina.com with about $90 \%$ of global economic activities depending on water [1]. Water resources provide the means of production and means of livelihood. It is the motive force of economic development and the security of social progress. For a country, water scarcity due to the cumulative effects of various drivers can make food and energy security very uncertain even within one year [2]. 
A water diversion project will transport water resources from water-abundant areas to water shortage areas, it is a way to redistribute and exploit water resources, thus the production of industry and agriculture can be promoted in the water-receiving areas.

Beijing is not only the political and cultural center of China, but also a world-renowned ancient capital and a modern international metropolis with a total area of $16,700 \mathrm{~km}^{2}$. As an extra-large infrastructure to solve Beijing's serious water shortage problem, the middle route of the South-to-North Water Diversion Project (MRSNWDP) has supplied water for the whole line since 2014 [3 4; Fig. 1]. Before water from the MRSNWDP was diverted, Beijing had to rely on excessive exploitation of underground water [5], which had restricted socio-economic development and ecological environmental health of the city. Beijing has cumulatively received 3.76 billion $\mathrm{m}^{3}$ of water so far. Only in 2015-2016, when about 1.104 billion $\mathrm{m}^{3}$ of incoming water was diverted, is it $105 \%$ of the planned volume (1.05 billion $\left.\mathrm{m}^{3}\right)$. The diverted water accounts for nearly $70 \%$ of the water supply of Beijing, which promoted the per capita water resources from $100 \mathrm{~m}^{3}$ to $150 \mathrm{~m}^{3}$. It not only covered the six major districts, but also Daxing, Mentougou, Tongzhou, etc. The water supply safety coefficient of the central city increased from 1.0 to 1.2 . The project greatly increases the water supply capacity and provides necessary water

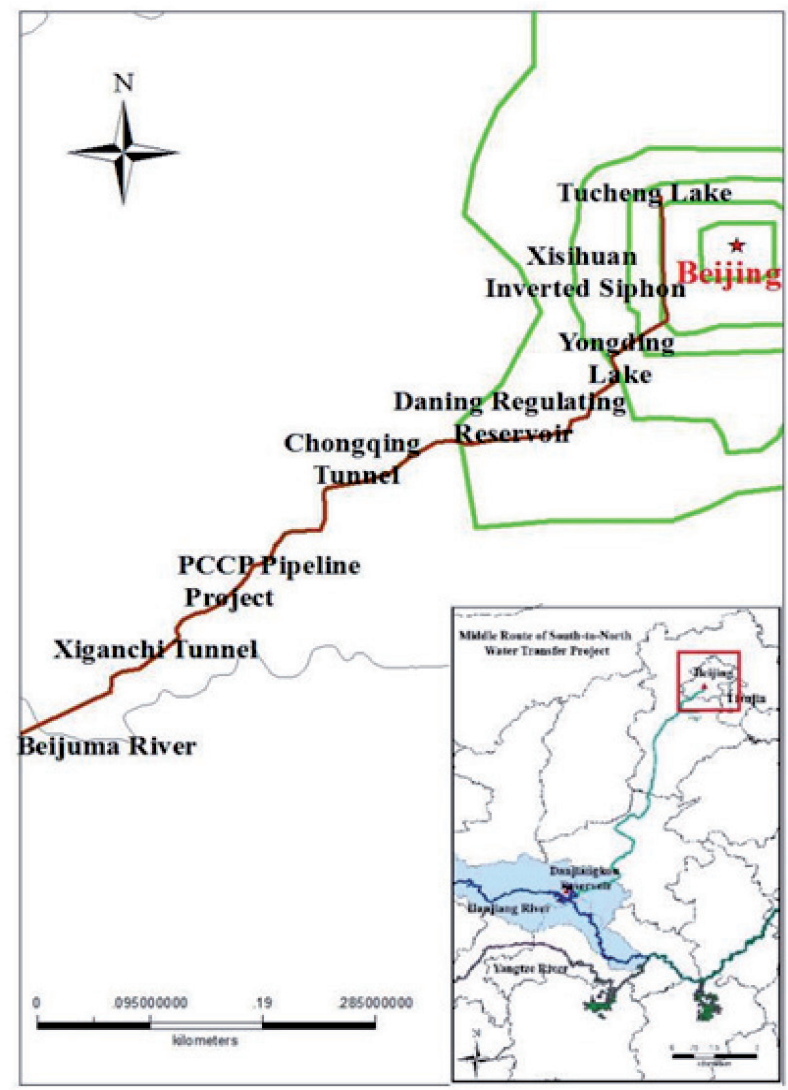

Fig. 1. Sketch map of the middle route of the South-to-North Water Diversion Project in Beijing. resources for production and living [6]. It also increases water resource security of the deputy center and the new airport of Beijing, which is related to sustainable development of Beijing.

Water services have an invaluable 'price' for the public budget and society's welfare [7], which is why evaluating a water diversion project's socio-economic impact quantitatively has become a hot issue around the world. The main approaches nowadays are statistical analysis method, econometrics, the production function method, input-output model and computable general equilibrium (CGE) model. However, the statistical analysis method requires a lot of statistics that are not readily available, such as the economic impact on national economies, watershed economies and industrial economies, so it is of little practical use. Econometrics rely too much on historical data, with inaccurate results and poor decision-making ability, so it is difficult to be used in policy impact assessment. The production function method is too simple and abstract to reveal the economic operation mechanism. The input-output model only reflects the transmission and restriction relationship among various industries in terms of quantity, and fails to take into account the impact of the market as a whole and market price on various industries. In this paper, the socio-economic impact of the South-to-North Water Diversion Project on Beijing is evaluated by the CGE model, which is calculated based on the general equilibrium theory, which reflects the economic activity of Beijing through a set of mathematical equations and can be taken as a microcosm of economics. Since Berck first applied the CGE model to water problems [8], it has been widely used in water resources research. Chou $\mathrm{C}$ built a single-country water resources CGE model (WATERGEM), which includes municipal water, surface water and groundwater, the simulation results show that water demand decreases when fees on water rights were imposed [9]. M Berrittella analyzed the effects of water scarcity due to the reduced availability of groundwater for investigating the role of water resources and water scarcity in the context of international trade [10]. Calzadilla A used the GTAP-W model to analyze the effect of potential water savings and the welfare implications of improvements in irrigation efficiency worldwide [11]. Hasan built the CGE model for water management which isolates the agriculture-irrigation industry to study the correlation of the agricultureirrigation industry and other industries and quantitatively evaluated the direct and indirect impacts on socioeconomic correlation of irrigation water management policy [12]. Wang Keqiang constructed a multi-regional CGE model to simulate the effects of multi-regional agricultural water efficiency and water resource tax policies in China [13]. Ma Jing [14] and Liu Y [15] used the multi-regional CGE model to quantify the impact of large-scale hydropower projects on the social economy and took the Chuan River of China as an example. Glyn constructed a dynamic TERM $\mathrm{H}_{2} \mathrm{O}$ model that could reflect the activities of water resources on the basis of 
the TERM model to study the impact of water resource shortages, policy changes and government spending [16]. However, the CGE models used in the literature have paid little attention to the following items: (1) the substitute relationship between various types of water sources; (2) total water constraint; and (3) the substitute relationship between capital and water resources.

To fill this gap in these areas, the paper builds an extended CGE model of the water resources in Beijing (BJCGE) to assess the socio-economic impact of delivered water supply in Beijing. In this model, water is divided into surface water, groundwater, reclaimed water, and south-to-north water, and a substitute relationship between them is established. A control module is designed to monitor total water consumption. The substitute relationship between capital and water resources is considered for the first time and the CES function is used to reflect the degree of mutual substitution between them. The base scenario of Beijing's socio-economic development is obtained when the water supply is at normal level and all variables in the model are set reasonably. Then the policy scenarios are added to the base scenario with insufficient or no supply of the south-to-north water to analyze the change of industrial structure, regional gross domestic product (GDP), the industrial employment structure, the price index $(\mathrm{CPI})$, the employment rate and per capita disposable income, etc.

The reminder of this paper is organized as follows. Section 2 introduces the theoretical basis and model structure, and constructs BJCGE. Section 3 sets the base scenario and policy scenario to analyze the socio-economic impact of a water diversion project. Section 4 concludes the paper. Section 5 provides some suggestions and future work prospects.

\section{Material and Methods}

\section{The Theoretical Basis of CGE}

The CGE uses a large number of linear or nonlinear equations to describe the demand, supply and relationships between them in the economic system [17]. The equations include the quantity variables of goods and production factors, and the price variables of commodity, elements, rate of capital return and transportation costs, etc. The equations depict the optimization behavior of economic subject, such as the producers wanting to maximize profits under the restrictions of certain cost and technical level or to minimize the costs with certain profit targets and technical levels; the consumers choose a reasonable combination of goods and services to maximize the utility within their budgets; the internationalist subject wants to minimize export costs and to maximize import benefits under certain profit targets, etc. Under series constraints of optimization, the equations are solved to obtain an optimal solution that can allocate resources reasonably and make all markets in an equilibrium state. In this way, the general equilibrium theory is expressed by mathematical equations and becomes a computable mathematical model which can be used to describe the economic system.

The CGE model synthesizes the economic link between different departments, optimizes the behavior subjects and reflects the impact of the relationship between external changes and endogenous variable on macro economy dynamically. The model can choose simulation scenario flexibly and analyze the economic system when some variable changes caused by policy changes or external influence, such as the price or quantity of goods and factors. As a whole, CGE describes the integrality of an economic system accurately.

\section{Model Structure}

The basic economic units analyzed by the CGE model are producers, consumers, governments and foreign economies.

\section{Production Behavior}

This mainly describes a producer's product supply. The producer tries to achieve profit maximization under the constraints of plant condition and resources. Two layers nested constant elasticity of substitution (CES) production function is used to simulate the investment of each department. Leontief function is used to describe the intermediate production demand for different industries, which allows an incomplete substitute relationship between different elements.

\section{Consumption Behavior}

In the conditions of given income level of consumers and commodity prices in the market, resident consumers have to make decisions of choice. They prefer to choose the commodities which can meet the goal that maximize consumer demands. The household consumption demand module is the same as the production module and investment demand module. It uses the form of twolevel nesting, but the Leontief function is replaced by the Stone-Geary utility function.

\section{Government Behavior}

Generally speaking, the role of government is to make relevant policies. In CGE, the variables about government are usually used as exogenous variables. Government revenue comes from taxes and fees and its expenditure includes public utilities, transfer payments and policy subsidies. Assume the government total expenditure changes along with the total consumption of residents, and a fixed ratio between them can be obtained from historical experience or empirical tests. 


\section{Foreign Trade}

With constant elastic transformation equation (CET), foreign trade can be described as the distribution of products in domestic markets and exports optimized to maximize the export product margin in the model [18]. The model assumes that the export demand is the inverted function of the price with foreign currency pricing, which is described by a downward sloping curve of the fixed price elasticity [19].

\section{Market Equilibrium}

The CGE model includes six equilibrium modules as follows:

1. Market equilibrium of commodities and factors.

The CGE model needs to meet the market equilibrium of commodities and factors or market clearing.

Market equilibrium of commodities: all the goods of enterprises produced is the sum of domestic product of intermediate input, domestic product of investment, domestic product of government spending, domestic product of household consumption, domestic products of export and domestic products of transport demand.

Market equilibrium of factors indicates that labor demand in each industry equals the total labor supply. The market clearing of the labor does not mean the full employment of labor, but a partial balance. Also, the capital demand of each industry is equal to total capital supply.

2. Enterprise income and expenses equilibrium.

Enterprises should maximize output under the established cost constraints or minimize the cost under the established output constraints. The income of the enterprise comes from capital income and transfer payment income. While expenditures include payment of labor remuneration and capital rents; pay taxes; savings. The CGE model considers that the production activities of the enterprise meet the balance of payments, i.e., total income is equal to total expenditure.

In the CGE model, the production activities of the enterprise meet the conditions of zero margin, i.e., total cost is equal to total revenue, total cost is the sum of apparent cost (factor cost of capital, land and labor market) and hidden cost (entrepreneurs own capital and their own management compensation). The sales activities of the enterprise also meet the conditions of zero margin, total cost of sales is equal to total income from sales, i.e., end user's purchase value is the sum of cost of production, circulation cost and sales tax. The zero margin of the sales activity realizes the organic connection between the producer's price with the price by buyers, such as enterprise, the residents, the export, the government and the inventory, the sales tax and the circulation price. The zero margin means there is no excess profit.
3. Household income and expenses equilibrium.

Residents provide labor factors and capital elements for enterprises, obtain labor remuneration or income, and consume goods, which is the driving force of economic and social development. For residents, income is the capital rent and wages paid by enterprise, plus the transfer payments from the government, while household expenditure includes consumer goods or services, personal income tax, and household savings. Residents maximize utility under certain budget constraints. The CGE model considers that the residents' income and expenses are balanced, namely the sum of capital income, labor remuneration, and transfer payment income is equal to the sum of residents' consumption, savings and individual income tax.

4. Government income and expense equilibrium.

The government's income comes mainly from taxes (including indirect taxes, income taxes, tariffs, etc.), as well as transfer payments. Indirect taxation is derived from the tax paid in the process of production and circulation of goods; income tax is the personal income tax paid by the residents; tariffs are the costs of importing goods or exporting goods. Government expenditure includes four aspects: consume domestic products; international expenditure; government savings; and transfer payment. The government realizes utility maximization under certain budget constraints. The CGE model considers that the government's income and expenses are balanced, i.e., the sum of indirect taxation, income tax, tariffs and transfer payment income is equal to the sum of government consumption, international expenditure, government savings and transfer payment expense.

5. International income and expenses equilibrium.

The CGE model contains macro-level balance of payments.

$$
N F L F_{+}=N F L F+C A D * \Phi
$$

...where NFLF means abroad net liabilities at the end of the year; NFLF means abroad net liabilities at the beginning of the year; $C A D$ means the current account deficit; and $\varnothing$ means exchange rate parameter. The value of each variable in equation (1) is calculated in foreign currency.

6. Capital market equilibrium.

The equilibrium of capital market, namely the equilibrium of investment savings, as shown in equation (2), the sum of the savings of governments, enterprises and residents has formed the investment of the next year, that is, total savings equal to total investment. If the total savings is not equal to total investment, the CGE model will make the rate of capital return exogenous (capital requirements are generally internal and external variables), through the price dynamic adjustment, eventually achieving the balance of the capital market.

$$
I N V E S T=S A V E
$$


Where INVEST means total investment, SAVE means total savings.

\section{Construction of the Model}

The GEMPACK platform is used to build the CGE model in the paper, which is developed by the policy research center--CoPS at Victoria University of Australia. It can solve various types of CGE models with a simple solution process, and its changeable modules make it suitable for policy analysis. The paper collects and integrates the water consumption information of economic society and different industry in Beijing. With rational analysis of the statistical data, a computable general equilibrium model of water resources in Beijing (BJCGE) is built to do mathematical simulation. Core modules of the model mainly are product production and distribution, household consumption, capital formation, investment decision making, export and other expenditure, price chain construction, supply and demand balance, and dynamic mechanism, etc. For the major economic activities such as production, consumption, and capital formation, their behavioral equation is constructed with the optimization principle, which can satisfy the hypothesis of rational economic man and are the same as other CGE models, for example minimizing the cost of a given product in production, minimizing the cost of investment, and maximizing consumer utility, etc. Artificial hypothesis or exogenous treatment is established for the economic behaviors that lack theoretical explanation.

The model is based on the input and output table and the macro-economic statistics of the research area, and the actual situation of water resources in Beijing is also considered. The improvements of this model are as follows:

\section{Construction of the Input-Output Table about the Subdivided Water Source}

According to actual survey data of regional subdivided water production and consumption, the water production and supply division are split into multiple water production departments. The input and output correction method in econometrics (namely the RAS method) is used to modify iteration. The input and output table of unified water resources- economic account is built to study the influence of adjusting the subdivided water price.

\section{Water Resource Replacement Module}

The total output of different industries is determined by the zero substitution combination of different intermediate inputs and supplements, and the Leontief production function is used in the model. As shown in Fig. 2, the output is determined by primary factors (capital, land, labor), water, commodity (imported product, domestic product) and other costs. To analyze the economic effects of adjusting the water price from different water sources, a single commodity water is divided into "surface water" (water from river, reservoir), "groundwater", "reclaimed water", and "south-to-north water" according to the water situation in Beijing. The substitute relationships between them are considered to be different. The improved model is able to simulate water structure changes caused by the relative changes of water price. The total amount of water consumption has no substitute relationship with other intermediate supplements. Various water sources replacement is realized by multi-layer nesting and it can reflect the difference of substitute impact between different water sources. According to the strength and

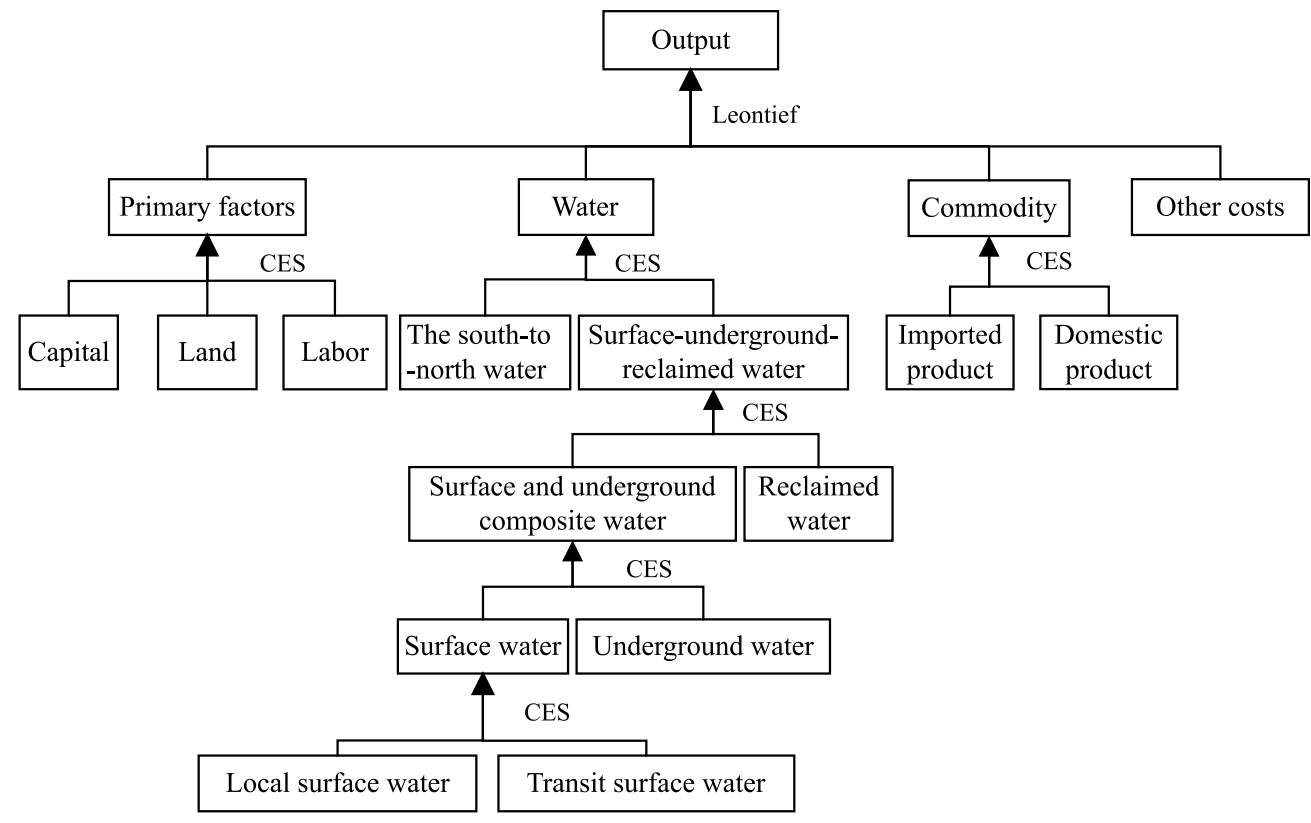

Fig. 2. Production module structure with subdivided water. 
probability analysis of the substitute relationship, the stratification and corresponding elasticity of substitution is set up.

The relationship between the upstream water and local water is considered, with Beijing's surface water source mainly coming from upstream water and groundwater. The paper considers that the two parts of water have a certain elasticity of substitution, and the CES function is used to combine them together.

$$
X_{i, j}^{(1)}=\underset{s=1,2}{C E S}\left\{\frac{X_{(i s) j}^{(1)}}{A_{(i s) j}^{(1)}} ; \rho_{i j}^{(1)}, b_{(i s) j}^{(1)}\right\} \quad(i, j=1, \ldots, n)
$$

...where $X_{i, j}{ }^{(1)}$ means the input raw water - the CES composite of local and upstream water; $X_{(i s) j,}^{(1)}, A_{(i s) j ;}^{(1)}$, and $b^{(1)}{ }_{(i s) j}$ represent the different sources of raw water, technological parameters and the share parameters used in sector $\mathrm{j}$; and $\mathrm{s}$ represents the source $(\mathrm{s}=1$ is local water; $\mathrm{s}=2$ is upstream water). $\rho_{i j}^{(1)}$ is the constant elasticity of substitution between local water and upstream water. Raw water means untreated water like surface water, groundwater and diverted water (tap water and reclaimed water are not included).

The substitute relationship between raw water and tap water is stronger compared to other water sources for high price difference. The substitute elasticity between them in different industries is given according to the survey, and the industry average value is about 1 [20]. With the rapid development of water reclamation technology, reclaimed water has the possibility to substitute the raw water and tap water in some industries. Assume that reclaimed water and the complex of tap water and raw water also satisfy the CES function, and the average substitute elasticity equals 0.5 [21], which is smaller than the value between raw water and tap water.

\section{Water Resource Constraint Processing Module}

According to the types of available water in Beijing, the water supply and demand balance constraint equation of raw water, tap water and reclaimed water is established. Since tap water comes from raw water, rational utilization of water resources can be regarded as optimal utilization of raw water. The supply and demand balance constraint of tap water mainly concerns the constraint relation of horizontal balance in the inputoutput table. Considering that the use of unconventional water sources is encouraged and the volume of it is not constrained theoretically, the process of reclaimed water is not reflected in this module. Only the total amount of

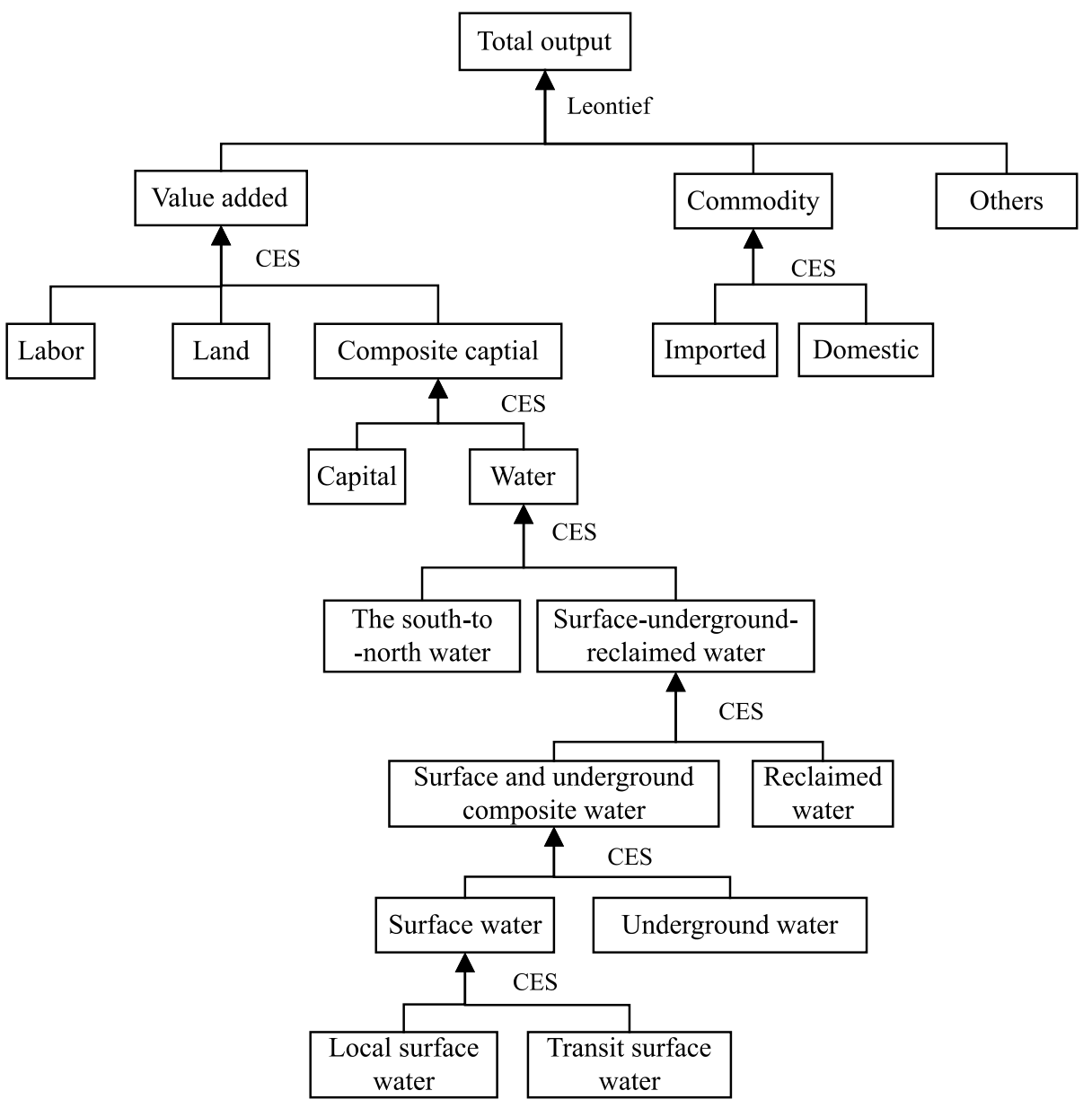

Fig. 3. Improved production module structure diagram of BJCGE model. 
raw water constrained function is added in the model, which is processed the same as capital, labor and land production factors.

\section{Capital and Water Substitute Module}

To make the utilization of water resources in the BJCGE model more accurate, the paper adds a new substitute module between capital and water to inspect the substitute relationship between different watersaving facilities (capital) and water resources. It also can inspect the impact of different water policies on different industry water consumption and capital. The multi-layer nesting method is used to realize the substitute relationship between different capital and water resources, which is shown in Fig. 3.

The study considers that there is a certain elasticity of substitution between capital and water resources, and the CES function is used to combine them, as shown in the following formula:

$$
\begin{gathered}
X_{\text {water_capital }, j}^{(1)}=C E S\left\{\frac{X_{\text {water_capita }, j}^{(1)}}{A_{\text {water_capita }, j}^{(1)}} ; \rho_{j}^{\text {water_capital }}, b_{\text {water_capital }, j}^{(1)}\right\} \\
(j=1, \ldots, n)
\end{gathered}
$$

...where $X_{\text {water capital, } j}^{(1)}$ means the amount of capital and water complex used during productive process by industry $\mathrm{j}$; $A^{(1)}{ }_{\text {water_capital, } j}$ means the technical parameter of capital and water complex used by industry $\mathrm{j} ; b^{(1)}{ }_{\text {water_capital,j }}$ means the proportion parameter of capital and water complex used by industry $\mathrm{j}$; and $\rho^{(1)}{ }_{\text {water capital, } j}$ means the constant substitute elasticity between capital and water complex.

\section{Results and Discussion}

\section{Scenario Setting}

Two scenarios are set in BJCGE. One is the social condition with water supply from the south-to-north water diversion project, which is referred to as the base scenario. The other one is social condition with insufficient water supply or completely no water supply from the south-to-north water diversion project, which is referred as the policy scenario. The difference of the future economic factors under these two scenarios can be used to access the social economic impact of Beijing's south-to-north water diversion project quantitatively.

\section{Base Scenario}

The base scenario is the foundation of policy simulation. The socio-economic data used in this model comes from the 'China statistical yearbook 2012-2015', the 'Beijing statistical yearbook 2012-2015', the 'Beijing national economic and social development statistical public report 2012-2015', the 'Input-output statistical yearbook of China 2012' and the 'Beijing input-output statistical yearbook 2012'. The water supply data is from the 'Beijing water resources bulletin 2012-2015' and onthe-spot investigation.

The macroeconomic parameters and industry categories are determined according to the study requirements. The macroeconomic parameters are valued according to the actual economic and social development of Beijing in 2012-2015. They include GDP, household consumption, investment, tertiary industry structure, employment, price level, etc. According to the statistics in 2012, there are 42 industries in Beijing. The water production and supply of these industries are subdivided into four categories: surface water, groundwater, reclaimed water and the south-to-north division water. Coal mining, petroleum mining and gas mining are integrated into one category which is named coal, petroleum and gas mining industry. With analyzing the input-output coefficient of the four categories, the input-output tables of the 44 departments in 2012 Beijing are obtained by using the horizontal balance correction iteration method (RAS).

Some parameters in the CGE model equation required calibration, for example the factors substitute elasticity of production function, consumer marginal consume priority, the demand and substitute elasticity of import and export, the transfer payments proportion of government and enterprises, and estimates of various tax rates, etc. There are two categories divided by the types of parameters:

1. The share parameters include the intermediate investment share of enterprise production activities, the consumption share of residents and government, the average savings rate, the import and export ratio, average tax rate, etc. They can be calculated indirectly from input-output tables or the functions in the model. The share parameters of different department import functions can be calculated from the proportion of different departments' domestic products and import products according to the base data, which equals the import value of different departments divided by the sum of the domestic production value and import production value. The efficiency parameter of different departments' import functions can be obtained by model calibration after substitute elasticity and share parameters are determined.

2. The elastic parameter includes the factor substitute elasticity of production function, the Frisch parameter of household consumption, the Armington elasticity of the import and export demand function, and the elastic coefficient of the export supply function, etc.

\section{Factor Substitute Elasticity}

The paper uses the economic method to count the capital and human resource data used by the industry of each region from the year 2000 to 2007. Theoretically, human resources should use actual input of standard human resource or working time, but limited to data, 
the paper use employed persons instead. Capital data use the total amount of fixed capital, the capital and employed person data of each region come from statistical yearbook or the statistical bulletin of each region from 2000 to 2015. Considering the statistical data cannot meet the requirement of agriculture, building industry and the tertiary industry, the paper uses the parameter values from the China Version of the ORANI-G model developed by MONASH University.

Two elements (capital and human resource) constant returns to scale production function:

$$
\mathrm{Q}=\gamma\left[\delta \mathrm{K}^{-\rho}+(1-\delta) \mathrm{L}^{-\rho}\right]^{-1 / \rho}
$$

...where Q is the output, $\mathrm{K}$ is the capital, I is the human resource, and $\delta$ is the proportion parameter.

$$
\rho=1 /(1+\rho)
$$

$\rho$ is substitute elasticity. If the elements (capital and human resource) are easier to replace, the greater value of " $\delta$ " will be. Take log of both sides of function (3) to linearize it and Taylor expand it at $\rho=0$, the linear formation of CES function obtained from the second order linear portion.

$$
\operatorname{zln}(\mathrm{Q})=\beta_{0}+\beta_{1} \ln (\mathrm{K})+\beta_{2} \ln (\mathrm{L})+\beta_{3}[\ln (\mathrm{K} / \mathrm{L})]^{2}
$$

...where $\beta_{0}=\operatorname{In}(\gamma), \beta_{1}=\delta, \beta_{2}=1-\delta$, and $\beta_{3}=-0.5 \rho \delta(1-\delta)$.

The substitute elasticity of industrial data from 2000 to 2007 is calculated with linear fitting.

\section{Armington Elasticity}

First order function of Armington elasticity:

$$
\frac{\mathrm{QM}_{\mathrm{c}}}{\mathrm{QD}_{\mathrm{c}}}=\left[\mathrm{PDD}_{\mathrm{c}} \cdot \delta_{\mathrm{c}} /\left(\mathrm{PM}_{\mathrm{c}} \cdot\left(1-\delta_{\mathrm{c}}\right)\right)\right]^{\frac{1}{1+\rho}}
$$

...where $\mathrm{QM}_{\mathrm{c}}$ is the import commodity amount; $\mathrm{QD}_{\mathrm{c}}$ is the domestic commodity consumption of domestic production; $\mathrm{PM}_{\mathrm{c}}$ is the commodity import price; and $\mathrm{PDD}_{\mathrm{c}}$ is the price of commodity which produced and consumed domestically. $\delta_{c}$ is the proportion parameter.

Take a log of both sides:

$$
y=\alpha+\beta x
$$

...where $y=\frac{\mathrm{QM}}{\mathrm{QD}}, \quad \alpha=\ln \left[\frac{\delta}{1-\delta}\right] /(1+\rho), \mathrm{x}=\frac{\mathrm{PDD}}{\mathrm{PM}}$.

It is the standard log function to estimate Armington elasticity. This function needs four kinds of data: the input commodity amount, the domestic commodity consumption of domestic production and their price. Some industries' data is difficult to get, so we used some parameter values in the Chinese version of the
ORANI-G model to do weighted average on the elastic data of some departments.

\section{The Elasticity of CET}

The estimation method of CET elasticity is similar to Armington elasticity. The efficiency parameter of different departments' import function can be obtained by model calibration after CET elasticity and share parameters are determined.

\section{Spending Elasticity of Residents Demand}

Based on the residents' consumption data from 2000 to 2007, the paper uses the least square method to calculate the expenditure elasticity of local residents' demand.

\section{Other Major Parameters}

Some parameter adjustment instructions are as follows.

1) Labor demand elasticity SLAB: using the estimate value of the China Academy of Social Sciences (CASS), 0.243.

2) Consumer price elasticity: using the value of CASS's the PRCGEM model, 4.

3) The substitute elasticity of capital and water resources, using the value of 0.5 .

4) Frisch parameter value, defined as the ratio of total revenue to total income minus the sum of basic requirements in LES (linear expenditure system demand function model). Studies show that the absolute value of the Frisch parameter decreases when the income of residents increases.

The table refers to 'Economic analysis CGE model and application' written by Zhao Yong, etc. [7]. The value is -0.14 .

\section{Policy Scenario}

The paper designs several policy scenarios to study the changing of the water supply structure in Beijing 2015 by setting different water supply amounts from the south-to-north water diversion project. Changing the water supply amount from the south-to-north water diversion project in 2015 and keeping the water supply from other water sources unchanged, it means

Table 1. Frisch variables calibration.

\begin{tabular}{|c|c|}
\hline Frisch--reference value & Economic situation \\
\hline-10 & Poorer \\
\hline-4 & Poor \\
\hline-2 & Middle income \\
\hline-0.7 & Wealthy \\
\hline-0.1 & Wealthier \\
\hline
\end{tabular}


Table 2. Designs under different policy scenarios.

\begin{tabular}{|c|c|c|c|c|c|}
\hline \multicolumn{2}{|c|}{ Scenario } & $\begin{array}{c}\text { Diversion water } \\
\text { supply }\left(* 10^{8} \mathrm{~m}^{3}\right)\end{array}$ & $\begin{array}{c}\text { Total water } \\
\text { supply }\left(* 10^{8} \mathrm{~m}^{3}\right)\end{array}$ & $\begin{array}{c}\text { Proportion of diversion } \\
\text { water supply of policy } \\
\text { scenario in base scenario }\end{array}$ & $\begin{array}{c}\text { Proportion of diversion water } \\
\text { supply in total water of base } \\
\text { scenario }\end{array}$ \\
\hline $\begin{array}{c}\text { Base } \\
\text { scenario }\end{array}$ & 0 & 7.55 & 38.2 & $90 \%$ & $19.76 \%$ \\
\hline \multirow{5}{*}{} & 1 & 6.8 & 37.45 & $80 \%$ & $17.80 \%$ \\
\cline { 2 - 6 } & 2 & 6.04 & 36.69 & $70 \%$ & $15.81 \%$ \\
\cline { 2 - 6 } & 3 & 5.29 & 35.94 & $60 \%$ & $13.85 \%$ \\
\cline { 2 - 6 } Policy & 4 & 4.53 & 35.18 & $50 \%$ & $11.86 \%$ \\
\cline { 2 - 6 } & 5 & 3.78 & 34.43 & $40 \%$ & $9.90 \%$ \\
\cline { 2 - 6 } & 7 & 3.02 & 32.92 & $30 \%$ & $7.91 \%$ \\
\cline { 2 - 6 } & 8 & 2.27 & 32.16 & $20 \%$ & $5.94 \%$ \\
\cline { 2 - 6 } & 9 & 1.51 & 31.41 & $10 \%$ & $3.95 \%$ \\
\cline { 2 - 6 } & 10 & 0.76 & 0 & $0 \%$ & $1.99 \%$ \\
\hline
\end{tabular}

no substitute water resources. Table 2 shows the 10 different policy scenarios used.

Evaluating the social economic impact of Beijing's south-to-north water division project based on the simulation results of BJCGE model under different policy scenarios, and the specific indicators include industrial structure, GDP, industrial employment structure, CPI, employment rate and per capita disposable income.

\section{Model Simulation Results and Discussion}

\section{Industrial Structure}

The paper uses the three-industry classification method to classify the industrial structure. The characteristics of water requirement in industry can be used to check the effects of south-to-north water diversion on the optimization of industrial structure and industrial layout in Beijing. The value-added proportion

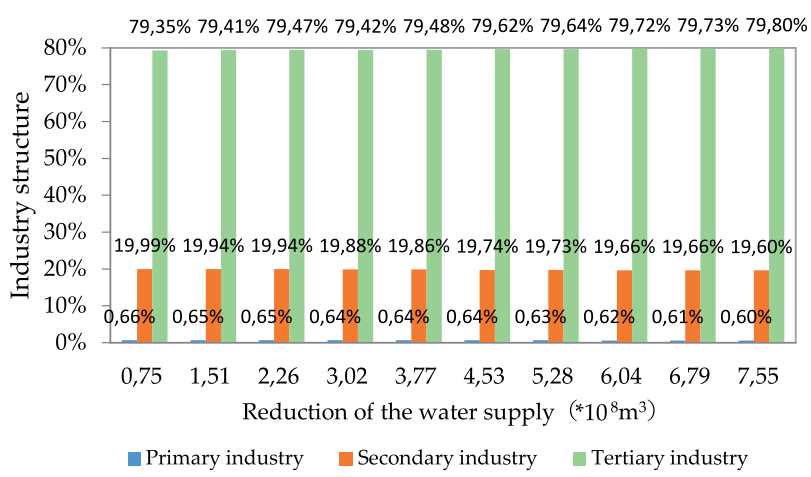

Fig. 4. Industrial structure changes under different policy scenarios. of primary industry, secondary industry and tertiary industry in Beijing in 2015 is 4.2\%, 18.0\% and $77.8 \%$ respectively under the base scenario. The changes of industrial structure under different policy scenarios are shown in Fig. 4.

Fig. 4 shows that as the reduction of the water supply from the south-to-north water division project under different policy scenarios, the industry structure of Beijing has a change tendency that the first industry decreases, the second industry decreases and the third industry increases.

In the second industry, the value-added proportion of high water consumption industry decreases while the value-added proportion of normal water consumption industry increases slightly, as shown in Table 3 . In the service industry, high water consumption industry like accommodation, catering and retailing and residential services decreases along with the reduction of total water supply in Beijing. Public service, transportation and communication are on the rise. Finance and others declines slightly.

\section{Gross Domestic Product (GDP)}

GDP is the market price of all the final products and services produced by all resident units in a country within a certain period of time. GDP is a core indicator of the national economic accounting and is an important indicator of the overall economic situation of a country or region. Water resources are closely related to economic development, and water shortage can lead to a decrease in economic aggregate. Under the base scenario, Beijing's GDP in 2015 is 2296.86 billion RMB and the change of GDP in different policy scenarios is shown in Table 4.

Table 4 shows that Beijing's GDP decreases along 
Table 3. Statistical table of three-industry structure changes under different policy scenarios.

\begin{tabular}{|c|c|c|c|c|c|c|c|c|c|c|c|c|}
\hline \multicolumn{2}{|c|}{ Scenario } & Base & 1 & 2 & 3 & 4 & 5 & 6 & 7 & 8 & 9 & 10 \\
\hline \multirow{4}{*}{ Reduction of water supply } & 0 & 0.75 & 1.51 & 2.30 & 3.02 & 3.77 & 4.53 & 5.28 & 6.04 & 6.79 & 7.55 \\
\hline & $\begin{array}{c}\text { Agriculture } \\
\text { Normal water consumption } \\
\text { industry }\end{array}$ & 0.895 & 0.910 & 0.920 & 0.900 & 0.930 & 0.930 & 0.946 & 0.950 & 0.961 & 0.960 & 0.968 \\
\cline { 2 - 11 } & $\begin{array}{c}\text { High water consumption } \\
\text { industry }\end{array}$ & 8.70 & 8.64 & 8.59 & 8.50 & 8.52 & 8.49 & 8.45 & 8.35 & 8.25 & 8.15 & 8.11 \\
\cline { 2 - 11 } $\begin{array}{c}\text { Rate of } \\
\text { change } \\
(\%)\end{array}$ & $\begin{array}{c}\text { Accommodation, catering retail } \\
\text { and residential services }\end{array}$ & 11.3 & 11.1 & 11.0 & 11.0 & 11.2 & 11.4 & 11.3 & 11.1 & 11.1 & 11.0 & 10.9 \\
\cline { 2 - 11 } & $\begin{array}{c}\text { Transportation } \\
\text { and communications }\end{array}$ & 14.3 & 14.4 & 14.6 & 14.0 & 14.4 & 14.1 & 14.7 & 14.5 & 14.6 & 14.7 & 14.8 \\
\cline { 2 - 11 } & Finance and others & 42.7 & 42.6 & 42.5 & 43.0 & 42.6 & 42.7 & 42.2 & 42.7 & 42.7 & 42.7 & 42.7 \\
\cline { 2 - 11 } & Public services & 8.10 & 8.11 & 8.12 & 8.10 & 8.15 & 8.16 & 8.17 & 8.18 & 8.19 & 8.20 & 8.21 \\
\hline
\end{tabular}

Notes: Hongzhen Ni put forward that using relative output coefficient of water consumption to differentiate high or low water consumption industry. Relative water consumption structure coefficient or relative water consumption coefficient $\geq 1$ is high water consumption industry, others are defined as normal water consumption industry [20]. Water consumption coefficient is the ratio between economic output and water consumption.

with the reduction of the water supply from the southto-north water diversion project under different policy scenarios. Generally, the decrease rate of GDP is smaller than the water supply reduction rate, but as further reduction of water supply, the GDP decrease rate has an increasing tendency. Under the scenario of no water supply from the south-to-north water diversion project, the total water supply of Beijing was reduced by $19.76 \%$ in 2015 . The GDP is 2046.69 billion RMB, which is reduced by 251.7 billion RMB compare to the base scenario, and the reduction accounts for $10.89 \%$ of Beijing's GDP in 2015. This situation is due to the influence of the economic system's self-regulation response mechanism.

\section{Industrial Employment Structure}

Industrial employment structure refers to the employment proportion of each industry and the employment proportion of three-industry reflects the state of employment structure in social structure.
This indicator can show whether the three-industry employment proportion change is influenced by water supply from the south-to-north water division project. The employment proportion of the primary, secondary and tertiary industries of Beijing in 2015 were $0.61 \%$, $19.71 \%$ and $79.68 \%$ respectively under the base scenario. The employment structure change of the three-industry under different policy scenarios is shown in Fig. 5.

Fig. 5 shows that along with the water supply reduction of the south-to-north water division project, the three-industry employment structure has a change tendency that the primary industry decreases, secondary industry decreases and tertiary industry increases.

Among the secondary industry, the employment proportion of the high water consumption industry has a decreasing tendency and the employment proportion of normal water consumption has a slightly increasing tendency. Among the tertiary industry, the industry structure of the high water consumption service industry like accommodation, catering and retailing has a decreasing tendency as the reduction of Beijing's

Table 4. The change of GDP under different policy scenarios.

\begin{tabular}{|c|c|c|c|c|c|c|c|c|c|c|}
\hline Scenario & 1 & 2 & 3 & 4 & 5 & 6 & 7 & 8 & 9 & 10 \\
\hline $\begin{array}{c}\text { Reduced diversion water } \\
\text { supply }\left(* 10^{8} \mathrm{~m}^{3}\right)\end{array}$ & 0.75 & 1.51 & 2.26 & 3.02 & 3.77 & 4.53 & 5.28 & 6.04 & 6.79 & 7.55 \\
\hline $\begin{array}{c}\text { Proportion of reduced } \\
\text { diversion water supply in total } \\
\text { water }\end{array}$ & $1.96 \%$ & $3.95 \%$ & $5.92 \%$ & $7.91 \%$ & $9.87 \%$ & $11.86 \%$ & $13.82 \%$ & $15.81 \%$ & $17.77 \%$ & $19.76 \%$ \\
\hline $\begin{array}{c}\text { Change rate of GDP } \\
\text { GDP }\left(* 10^{8} \mathrm{RMB}\right)\end{array}$ & $-0.44 \%$ & $-0.90 \%$ & $-1.47 \%$ & $-2.23 \%$ & $-3.36 \%$ & $-4.26 \%$ & $-5.34 \%$ & $-6.89 \%$ & $-8.77 \%$ & $-10.89 \%$ \\
\hline Reduction value $\left(* 10^{8} \mathrm{RMB}\right)$ & 100.8 & 206.3 & 336.9 & 511.1 & 770.6 & 978.0 & 1225.4 & 1583.2 & 2015.3 & 2501.7 \\
\hline
\end{tabular}




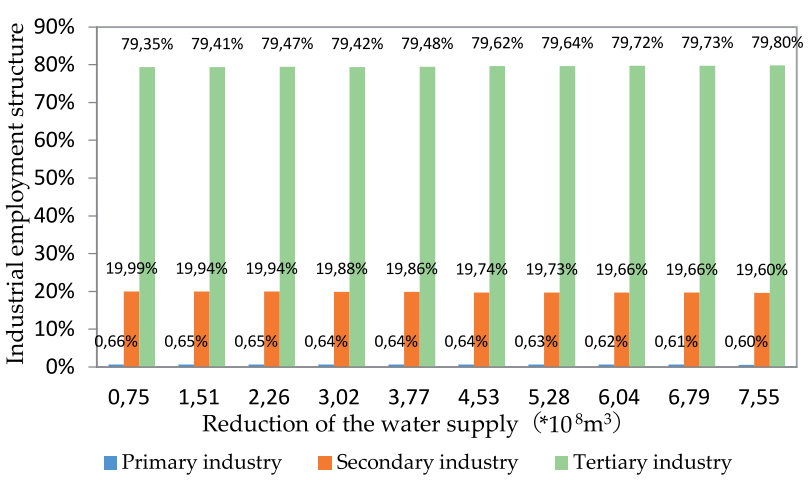

Fig. 5. The employment structure change of the three-industry under different policy scenarios.

total water supply; public service, transportation and communication have an increasing tendency; financial and others have a slightly decreasing tendency. The three-industry employment structure has the same change tendency as the industrial employment structure under different policy scenarios (Table 5).

\section{Commodity Price Index (CPI)}

CPI is equal to dividing the sum of the product of commodity price and its weight in the calculation period by the sum of the product of commodity price and its weight in the base period. Maintaining CPI stable is a top priority for the government. Under base scenario, Beijing's CPI in 2015 was 101.8, and the change of CPI under different policy scenarios is shown in Fig. 6.

Fig. 6 shows that the reduction of water supply from the south-to-north water division project under different policy scenarios, which result in a producer's water shortage during production, then the enterprises will use substitute elements or water-saving equipment,

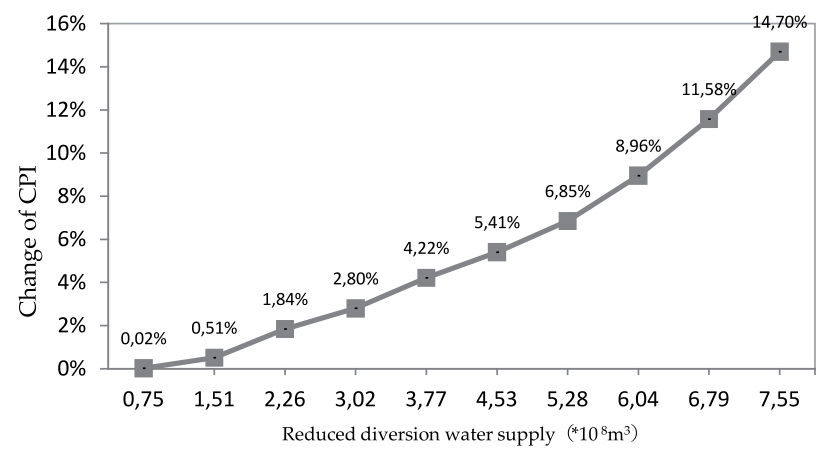

Fig. 6. Change of CPI under different policy scenarios.

this action will increase the production costs and output price that lead to CPI rising finally. CPI is an important indicator of inflation, as the change rate of CPI reflects the degree of inflation or deflation. In general, CPI inflation of $3-5 \%$ is an international warning line for inflation. The reduction of water supply from the southto-north water diversion project should be controlled under 302 million $\mathrm{m}^{3}$, which is a safety field.

\section{Employment Rate}

The employment rate refers to the percentage of the employed population to the total population aged 16 and above, which is closely related to the vital interests of people and social stability. Water scarcity can lead to economic decline and lower employment. Under the base scenario, the number of people employed in Beijing in 2015 was 11,937,000, the employment rate is $69.06 \%$ and unemployment rate $1.39 \%$. The change of employment rate under different policy scenarios is shown in Table 6.

The constraint of the model is water supply, the reduction of water supply results in a producer's water

Table 5. Statistics of three-industry employment structure changes under different policy scenarios.

\begin{tabular}{|c|c|c|c|c|c|c|c|c|c|c|c|c|}
\hline & Scenario & Base & 1 & 2 & 3 & 4 & 5 & 6 & 7 & 8 & 9 & 10 \\
\hline \multicolumn{2}{|c|}{ Reduction of water supply } & 0 & 0.75 & 1.51 & 2.26 & 3.02 & 3.77 & 4.53 & 5.28 & 6.04 & 6.79 & 7.55 \\
\hline \multirow{8}{*}{$\begin{array}{l}\text { Rate of } \\
\text { change } \\
(\%)\end{array}$} & Agriculture & 4.200 & 4.210 & 4.212 & 4.214 & 4.218 & 4.222 & 4.227 & 4.23 .0 & 4.231 & 4.232 & 4.238 \\
\hline & $\begin{array}{c}\text { Normal water consumpti- } \\
\text { on industry }\end{array}$ & 8.074 & 8.266 & 8.421 & 8.558 & 8.765 & 8.774 & 8.855 & 8.905 & 9.012 & 9.089 & 9.104 \\
\hline & $\begin{array}{l}\text { High water consumption } \\
\text { industry }\end{array}$ & 3.945 & 3.889 & 3.828 & 3.809 & 3.782 & 3.877 & 3.764 & 3.701 & 3.662 & 3.647 & 3.614 \\
\hline & Building industry & 4.413 & 4.382 & 4.352 & 4.321 & 4.290 & 4.259 & 4.228 & 4.197 & 4.167 & 4.136 & 4.105 \\
\hline & $\begin{array}{l}\text { Accommodation, catering } \\
\text { retail and residential } \\
\text { services }\end{array}$ & 14.870 & 14.857 & 14.840 & 14.822 & 14.820 & 14.804 & 14.765 & 14.646 & 14.594 & 14.519 & 14.438 \\
\hline & $\begin{array}{c}\text { Transportation } \\
\text { and communications }\end{array}$ & 15.859 & 15.901 & 15.921 & 15.977 & 15.982 & 16.059 & 16.123 & 16.374 & 16.516 & 16.681 & 16.863 \\
\hline & Finance and others & 35.095 & 34.932 & 34.847 & 34.702 & 34.502 & 34.235 & 34.283 & 34.152 & 33.984 & 33.822 & 33.725 \\
\hline & Public services & 13.543 & 13.563 & 13.58 & 13.598 & 13.642 & 13.77 & 13.755 & 13.795 & 13.835 & 13.874 & 13.914 \\
\hline
\end{tabular}


Table 6. The situation of employment and unemployment under different policy scenarios.

\begin{tabular}{|c|c|c|c|c|c|c|c|c|c|c|}
\hline Scenario & 1 & 2 & 3 & 4 & 5 & 6 & 7 & 8 & 9 & 10 \\
\hline Reduction of water supply $\left(* 10^{8} \mathrm{~m}^{3}\right)$ & 0.75 & 1.51 & 2.26 & 3.02 & 3.77 & 4.53 & 5.28 & 6.04 & 6.79 & 7.55 \\
\hline Employment rate change & $-0.17 \%$ & $-0.45 \%$ & $-1.10 \%$ & $-1.66 \%$ & $-2.48 \%$ & $-3.17 \%$ & $-3.98 \%$ & $-5.15 \%$ & $-6.57 \%$ & $-8.21 \%$ \\
\hline Quantity of employment $\left(* 10^{4}\right)$ & 1191.7 & 1188.3 & 1180.6 & 1173.9 & 1164.1 & 1155.9 & 1146.1 & 1132.2 & 1115.0 & 1095.6 \\
\hline Employment rate & $68.90 \%$ & $68.70 \%$ & $68.30 \%$ & $67.90 \%$ & $67.30 \%$ & $66.90 \%$ & $66.30 \%$ & $65.50 \%$ & $64.50 \%$ & $63.40 \%$ \\
\hline $\begin{array}{c}\text { The quantity of increased } \\
\text { unemployment }\left(* 10^{4}\right)\end{array}$ & 1.970 & 5.410 & 13.14 & 19.84 & 29.64 & 37.79 & 47.52 & 61.45 & 78.38 & 98.05 \\
\hline Unemployment rate & $1.74 \%$ & $2.34 \%$ & $3.71 \%$ & $4.89 \%$ & $6.61 \%$ & $8.05 \%$ & $9.76 \%$ & $12.2 \%$ & $15.2 \%$ & $18.7 \%$ \\
\hline
\end{tabular}

shortage during production. Water shortage causes the production costs and the output price rise, and then the average wage rises compared to the comprehensive element prices and unemployed people. Table 6 shows that the unemployment rate rises along with the reduction of water supply from the south-to-north water division project. If we were to cancel this project, the number of unemployed people would be 10.956 million and the increased number would be about 0.9805 million. At present, the Chinese unemployment warning line is $7 \%$ according to the consensus of experts from the Delphi survey. If the unemployment rate exceeds this threshold, it will lead to dissatisfaction, social instability and a series of anti-social behaviors. The reduction of water supply from the south-tonorth water diversion project should be controlled under 377 million $\mathrm{m}^{3}$, which belongs to the security field. According to the statistics from the provincial panel data, the registered urban unemployment rate and the criminal crime rate have a positive correlation coefficient, which is 0.0365 . With the increase of unemployment, the social environment will worsen.

\section{Per Capita Disposable Income}

Per capita disposable income is usually the average of personal disposable income. Personal disposable income refers to the income with all government taxes and non-commercial expenses deducted. Personal disposable income is considered the most important determining factor of consumer spending, so it is often used as the measurement of a country's living standard. It can reflect the comprehensive effect of wage and expenditure. With the water supply guarantee rate in Beijing increasing, economic development will be promoted, which usually leads to higher wages and higher expenditures. This indicator can be used to evaluate the water supply's impact on people's living standard indirectly. The per capita disposable income of Beijing in 2015 is 48458 RMB under base scenario, and the change of per capita disposable income under different policy scenarios is shown in Table 7.

Table 7 shows that with the reduction of water supply from the south-to-north division project, the per capita disposable income decreases and people's living standards decline together. Under the scenario of without water supply from the south-to-north water diversion project, the per capita disposable income is 46,421 RMB, which is 2,037 RMB less than the base scenario.

\section{Conclusions}

Our paper constructs the general equilibrium model of Beijing (BJCGE), and some conclusions are obtained according to the simulation results.

1. The proportion of the high water consumption industry decreases along with the reduction of water supply from the south-to-north water diversion project under different policy scenarios.

2. GDP decreases along with the reduction of the water supply from the south-to-north water diversion project under different policy scenarios. Generally, the decrease rate of GDP is smaller than the water supply reduction rate, but as further reduction of water supply, the GDP decrease rate has an increasing tendency.

Table 7. Per capita disposable income and reduction under different policy scenarios.

\begin{tabular}{|c|c|c|c|c|c|c|c|c|c|c|}
\hline Scenario & 1 & 2 & 3 & 4 & 5 & 6 & 7 & 8 & 9 & 10 \\
\hline $\begin{array}{c}\text { Reduction of water supply } \\
\left(* 10^{8} \mathrm{~m}^{3}\right)\end{array}$ & 0.75 & 1.51 & 2.26 & 3.02 & 3.77 & 4.53 & 5.28 & 6.04 & 6.79 & 7.55 \\
\hline $\begin{array}{c}\text { Per capita disposable income } \\
\text { change rate }\end{array}$ & $-0.16 \%$ & $-0.35 \%$ & $-0.56 \%$ & $-0.85 \%$ & $-1.27 \%$ & $-1.62 \%$ & $-2.04 \%$ & $-2.63 \%$ & $-3.36 \%$ & $-4.20 \%$ \\
\hline Per capita disposable income & 48379 & 48291 & 48185 & 48046 & 47842 & 47673 & 47471 & 47182 & 46830 & 46421 \\
\hline The reduced value & 79 & 167 & 273 & 412 & 616 & 785 & 987 & 1276 & 1628 & 2037 \\
\hline
\end{tabular}


3. The three-industry employment structure will change along with the reduction of water supply from southto-north water diversion project, primary industry and secondary industry increases but tertiary industry decreases - especially the proportion of high water consumption industry.

4. If the reduction of water supply from the south-tonorth water diversion project is higher than 302 million $\mathrm{m}^{3}$, there will be a risk of inflation. This situation is harmful to social stability and the CPI will increase significantly, so the reduction of water supply is advised to be controlled at fewer than 302 million $\mathrm{m}^{3}$.

5. With the scenario of no water supply from the southto-north water diversion project, the amount of people employed is about 109.56 million, the amount of people unemployed increases about 9.805 million compare to base scenario. From the point of social stability and safety, the reduction of water supply from the south-to-north water diversion project is advised to be controlled at fewer than 377 million $\mathrm{m}^{3}$.

6. With the scenario of no water supply from the south-to-north water diversion project, the per capita disposable income is 46421RMB, reduces a2037RMB compared to the base scenario, so the living standards decline.

According to the conclusions above, we have the following suggestions:

1. Allocate water reasonably. Water should be allocated according to different water sources, quality and prices. All the demands of the regional economic, environment and ecology should be comprehensively considered to improve the efficiency of water resource utilization to maximize the comprehensive benefit of limited water resources, to realize the sustainable utilization of water resources, to provide water support to the development of social economy and the protection of ecological environment, and finally to realize the reasonable water resource allocation between contemporary people, between different generations, and between human society and the natural environment.

2. Encourage using reclaimed water. The using of reclaimed water in China starts gradually now. The government should take some measures to encourage it, for instance, low-cost operation mode, which widens the price gap between reclaimed water and tap water and which will stimulate some industries changing to reclaimed water if they have the possibility to use reclaimed water instead of raw water or tap water.

3. Optimize industry structure. Beijing belongs to water resource shortage cities, so the restriction of water resources should be fully considered when making economic development plans. The development speed and scale of the high water consumption industry should be restrained. The low water consumption and high output industry should be encouraged in pursuit of rapid sustainable development of the economy.
The high water consumption and high output industry should be moved to areas with abundant water resources. The low output and high water consumption industry should not arrange or restrict their water supply demand.

4. Develop alternative water sources. On the one hand developing water-saving technologies, improving water-saving efficiency and enhancing water-saving awareness, on the other hand carrying out the research of water-saving products actively, increasing the promotion of water-saving equipment and expanding the use of unconventional water sources such as rainwater, reclaimed water, and desalination of seawater, etc. Developing and seeking alternative water sources is an important way to reduce the supply pressure of conventional water sources and alleviate the water crisis.

5. Set a reasonable price spread. To promote the establishment of water-saving industrial structure and economic transformation, the price difference of water between high water consumption industry and normal water consumption industry should be further widened. To promote the productivity layout which adapts to the conditions of water resources, the water price difference between water shortage areas and abundant areas should be further widened, especially the regional water price difference to high water consumption industry, so the abundant areas will appeal to the high water consumption industry. To encourage the development and utilization of unconventional water sources, the water price difference between conventional water source (water conservancy water and tap water) and unconventional water (reclaimed water and desalination of water) should also be further widened. To ensure the rational allocation of water resources and to safeguard the normal operation of diversion, the prices of local surface water, groundwater and the diverted water should be established reasonably. The pricing of water should make the diverted water have a higher priority or at least the same demand as the local water. Considering the water use fairness of vulnerable groups, the price of water should have a reasonable gap between urban and rural areas, between different income levels.

6. Improve government regulation. China has always regarded the water industry as a public welfare cause. The government is both a policy maker, a supervisor and a business operator, so there are many problems in the operation of water utilities. The functions of the government are not clearly defined, supervision is not strong enough, and there are loopholes in the supervision content. The lag of government supervision makes the new business of the tax industry not timely included in the scope of government supervision, which hinders the marketization of water utilities. The government can integrate the regulatory experience of governments around the world, improve the water legal system 
and establish efficient management institutions, and set up professional and independent regulatory departments to supervise the healthy development of the water market.

7. Utilize market regulation. China has numerous water conservancy projects and most of them can't review assets clearly for lacking a perfect statistical accounting system. The water conservancy projects are regard as public utilities in the past, so the price of the diverted water is very low. Without stable income, the water conservancy projects are aged and fall into disrepair, some of them are even difficult to maintain normal operation, which not only affects water use efficiency but also makes the water conservancy projects not play the role of promoting watersaving. Scientific market price adjustment will be an important measure in China. The environmental policy of China turns to market gradually now, so introducing market mechanisms to the allocation of water resources and using the method of economy and the stimulation of the market will accelerate the reform progress of water management, water market and water price.

8. Due to lacking support of a complete information database, some parameters in the model are difficult to be determined, so the abundance of data and information should be improved to make the model more accurate.

\section{Acknowledgements}

Our research has been supported by the State key Basic Research and Development Plan of China (2013CB036406) and Priority Academic Program Development of Jiangsu Higher Education Institutions (PAPD) of China. The authors thank the reviewers for their helpful comments, and appreciate the professionalism shown by the editors.

\section{Conflict of Interest}

The authors declare no conflict of interest.

\section{References}

1. European Water Platform. WssTP, a common vision for water research and innovation. Slide 5 of the powerpoint presentation, 2015.

2. HAIE N. Sefficiency (Sustainable efficiency) of WaterEnergy-Food Entangled Systems. International Journal of Water Resources Development. 32 (5), 721, 2016.

3. HUW POHLNER Institutional change and the political economy of water megaprojects: China's south-north water transfer. Global Environ. Change. 38, 205, 2016.

4. Proje O.T.N.W.D. The South-to-North Water Diversion Project. Engineering. 2 (3), 265, 2016.

5. MA Z., FANG Z., XIE X., CHAI F., ZHANG Q. Study on feature storage and storage capacity of underground reservoir based on GMS in MHS area of Beijing, China. Arab. J. Geosci. 8 (12), 10359, 2015.

6. ZHUOYUE PENG, LILI ZHANG, JUNXIAN YIN, HAO WANG A Study of Impact Factors of Willingness to Pay about Water Reserve of the South-to-North Water Diversion Project in Beijing Based on the Bayesian Network Model, Journal of Cleaner Production. 184, 569, 2018.

7. PINTO F.S., SIMÕES P., MARQUES R. Water services performance: do operational environment and quality factors count?. Urban Water Journal. 14 (8), 773, 2017.

8. BERCK P., ROBINSON S., GOLDMAN G. The use of computable general equilibrium models to assess water policies. Economics \& Management of Water \& Drainage in Agriculture. 52 (3), 489, 1990.

9. CHOU C., HSU S., HUANG C. Water Right Fee and Green Tax Reform: A Computable General Equilibrium Analysis. Purden University, West Lafayette. 2001.

10. BERRITTELLA M., HOEKSTRA A.Y., REHDANZ K., ROSON R., TOL R.S. The economic impact of restricted water supply: a computable general equilibrium analysis. Working Papers. 41 (8), 1799, 2006.

11. CALZADILlA A., REHDANZ K., TOL R.S.J.. Water scarcity and the impact of improved irrigation management: a CGE analysis. 2007.

12. HASAN DUDU, SINQOBILE CHUMI Economics of Irrigation Water Management: A Literature Survey with Focus on Partial and General Equilibrium Models. Policy Research Working Paper. 3, 65, 2008.

13. WANG KEQIANG, DENG GUANGYAO, LIU HONGMEI Water Utilization Efficiency in Agriculture and Policy Simulation of Water Resources Tax in China Based on Multi-regional CGE Model. Journal of Finance and Economics. 41 (3), 40, 2015.

14. MA JING, LIU YU Economic Impact Assessment of Large-scale Hydropower Project based on Computable General Equilibrium Model. Journal of Hydroelectric Engineering. 34 (05), 166, 2015.

15. LIU Y., MA J., WANG H., YAN D.H., LV Y.K., DENG W. Multi-dimensional assessment of socioeconomic impacts of hydropower development-A case in the Upper Chuan River. Science China Technological Sciences. 58 (7), 1272, 2015.

16. WITTWER G., WIRTSCHAFT A. Wasserwirtschaft, Regionalökonomie, Ökonomische Modelle. Economic Modeling of Water. Springer Netherlands. 2012.

17. ZHAO JING, HUA XIAO-LI, NI HONG-ZHEN, WANG LIKUN, YU JING Economic impact of water investment based on CGE model-A Case of Heilongjiang Province. Journal of Natural Resources. 28 (4), 696, 2013.

18. ZHAO J., NI H., PENG X., LI J., CHEN G., LIU J. Impact of water price reform on water conservation and economic growth in China. Economic Analysis \& Policy. 51, 90, 2016.

19. EILEEN W., MERYL P., LOREEN M., BRADLEY J., JOHN M. Perceptions of water pricing during a drought: A case study from South Australia. Water. 25 (1), 197, 2013.

20. NI HONGZHEN, WANG HAO, LI JIFENG, ZHANG CHUNLING, ZHAO JING Study on water supply price system. China Water Power Press, China, 2016 [In Chinese].

21. ZHAO JING Economic Impact of Water Investment Based on CGE Model-As a Case of Heilongjiang Province. Northeast Agricultural University. 2013 [In Chinese]. 